Title:

\title{
New Public Management and Practitioner Autonomy in Children's Services in Norway and Wales: Views from the Frontline
}

\begin{abstract}
The article examines aspects of professional autonomy informed by cross sectional surveys of social workers in Wales (UK) and Norway. The data show that in Wales there is circumscribed autonomy whereby rule compliance is both expected and scrutinised, and practitioners are more likely to spend time as a 'screen-worker', fettered by austerity, riskfocused and safety-oriented towards children. The Norwegian sample appears to enjoy frontline freedoms to utilise discretion in delivering bespoke preventive services and are much more likely to spend time at 'street-level' working in a child welfare and family focused approach. Despite these profound differences between the two samples, both sets of practitioners consider their administrative duties to be an important feature of practice rather than an unwarranted diversion from direct work; participants in both countries consider their work to be of quality and most look forward to going to work. These and other variations and similarities in the data are discussed in light of relevant system features and policy.
\end{abstract}

Keywords: Children's services, discretion, decisions, autonomy, quality of work 


\section{Main text:}

\section{Introduction}

This article first discusses occupational conditions regarding autonomy and discretion for Welsh and Norwegian social workers in contemporary child and family work. We then proceed to contextualise our discussion with findings from national on-line surveys we conducted with registered practitioners in Norway and Wales (UK). Were we to position the child and family social work systems in light of Esping-Andersen's (1989) classic typology, then Norway which has long enjoyed the reputation of an inclusive welfare state, would be cast as social-democratic. Wales by contrast is, largely through the exigencies of longrunning UK-wide public funding cuts, linked more to the targeted work-fare state of a neoliberal tradition. Given these profound national policy differences, the work orientations of child and family social workers should provide important comparative insights into the way work is conducted and understood to be effective (or not) by professionals, and what this might infer about the occupational experience in these two very different state jurisdictions.

\section{Professional Autonomy}

A key feature of professional identity resides around the notion of practice autonomy and discretion over decision making. In addressing this theme, we also consider related matters of practice orientation, the quality of work performed and issues of resource. These and other key variables are analysed to help underpin our central discussion about the impact of the occupational context on professional autonomy. Conceptually, we view autonomy as an anticipated desire among professionals to control their own work, based upon judgements and decisions they make related to their formal knowledge and work experience (Freidson, 2001). A key means to sustain practitioner autonomy is to ensure that professionals are endowed with a wide range of opportunities to exert discretion in their practice. Discretion is related to 
exercising individual professional judgements and related decisions about what seems reasonable to do in specific cases (Grimen \& Molander, 2008) and it often defies standardised approaches to decision making. Discretion implies a need for the professional agent to be protected from overly constraining institutional environments. However, discretion is never context-free, particularly so in a 'bureau' profession such as social work whereby its location in Norway and Wales, respectively within the municipal and local authority system, makes it subject to regulatory control and management oversight.

Furthermore, over recent decades there has been the global impact of neo-liberal New Public Management (NPM) reform focusing on efficiencies and market principles in order to steer the public professions towards more unitised and controllable practices (Hood \& Dixon, 2015). A defining characteristic of NPM is typically one of diminishing the spheres of professional autonomy in human service organisations through various forms of benchmarking, surveillance, evidence based practices, accountability, documentation and work-flow routines that shift power from professionals to the realm of a more marketized public service economy and related state interests (Author`s own, 2015). In exploring selective aspects of these administrative and professional environments we draw upon two broad orientations to autonomy that have informed our study design and interpretation of findings.

\section{Orientation 1: Autonomy under pressure}

The relevance of this orientation to Wales can be evidenced in a much described history of unwelcome rigid and standardised approaches to practice in children's services shaped by the use of screen-based process and time-line systems that attracted considerable criticism from the occupation in the way this impaired professional judgement and essential flexibility of operations (Wastell et al., 2010). There have been claims that the Norwegian Child 
Welfare Services are also exposed to external control by the state linked to expectations that services will be efficient and will employ particular evidence-based methods such as MultiSystemic Therapy (MST), Parent Management Training (PMTO), Webster Stratton and Functional Family Therapy (Nordstoga \& Støkken, 2009; Gautun, 2009) thereby limiting the intervention choices that workers offer.

However, elements of the literature that informs this Orientation have been criticised for assuming that regulatory systems and guidance act in some immutable fashion, overlooking how professionals may moderate the impact of policy and procedures given the interstitial freedoms they may enjoy at 'street-level' (Newman, 2014).

\section{Orientation 2: A Space for Autonomy}

This perspective looks to the differing frames surrounding human service work formulated by parliaments and ministries but mediated by managers and workers (Frostenson, 2015). Some social work policies will necessarily be vaguely formulated, interpretable and involve working with 'wicked issues' where uncertain causal relationships continue to challenge the efficacy of human service interventions (Dubois, 2010; Hupe, 2013). Thus, Evans and Harris (2004) questioned the prevailing pessimism in much UK social work literature over the loss of professional autonomy and deemed it an exaggeration that discretion had either vanished or been decisively reduced. They argue that in a complex bureaucratic structure the rules and frames of practice create space where professionals can exert a degree of autonomy in respect of compliance and interpretation. Likewise in Norway, children's services that are residential-based evince a clear formal control system established to standardise quality but this exists alongside day to day practices in the settings in which discretion appears extensive (Nordstoga \& Støkken, 2009). We might agree that in both Wales and Norway workers in local state bureaux enjoy variable degrees of autonomy which is difficult for administrators to 
reduce or remove. Much depends upon the organisational context and nature of work itself and it is towards this realm that we turn next.

\section{The Child Welfare Services System in Norway \& Wales}

The choice of these two small western coastal European countries was informed by the shared professional values and skills of their local authority or municipal-based social workers. Relatedly, it was considered that the different policy and administrative systems that are thought to shape practice in what is essentially a strongly preventive social democratic Norway and a more targeted crisis-focused cash-limited Wales would surface valuable comparative insights into practitioner attitudes and experiences.

In Norway, the Child Welfare Services Act (1992) is the primary legislation that shapes state action, guidelines and instructions of a general nature. The legislation contains general and familiar principles (albeit sometimes in tension - see Kritz \& Skivenes, 2014) such as 'the best interest of the child', 'the least intrusive measure to the family' as well as 'the biological principle' surrounding the child's ideally permanent links to its family. While the Act provides a dual structure linking interventions and preventive work, the associated guidelines for practice tend to reside at the level of general principle rather than explicit requirements around practice. Whilst municipal services are required to follow timelines, such as into notifications of concern, in doing so there are multiple opportunities to use discretion when it comes to intervening or not, and in following up on initial responses (Molander 2013).

The Ministry of Children and Equality and the Norwegian Directorate for Children, Youth and Family Affairs has as their goal to provide children, young people and families in need of help and support with appropriate, high-quality interventions nationwide. The Ministry funds

a national directorate that is basically an accredited centre for determining best practice in child welfare and family counselling. Ministry and Directorate can instruct subunits at 
regional and municipal levels. Additionally, the state-funded 'Bufetat' assists local services in relation to placements of children outside of the family, recruiting foster carers and providing training and counselling. It offers municipalities support in delivering treatment programmes to help prevent placement of children outside the home, notably MST and PMTO. These were introduced at the end of the 1990s in line with ministerial policy that child welfare services should draw upon evidence-based methods (Krogh, 2009). The Ministry, Directorate and Bufetat can be seen jointly as shaping the institutional orientation of the municipal Child Welfare Service since they seek to appropriate local discretion and shape practice through administrative mechanisms and approved interventions (March \& Olsen, 1989).

All municipalities are required by law to have a Child Welfare Service. These claim a broad prevention repertoire of interventions promoting child development; enhancing parenting skills; organising inter-agency responses to connect support groups (Statistics Norway 2018). Social workers provide advice and counselling to families, reach decisions around care proceedings, and implement follow up plans. In essence there is a dual mandate to investigate and intervene where children are living under unacceptable family conditions, and at the same time contribute to a general aim of prevention. This duality calls forth discretionary judgments by workers to determine how much effort is to be placed on these respective goals. While investigations must first follow statutory time-lines what follows thereafter is very much a matter of professional judgement and decision about whether to refer a case to other support agencies, or to determine that matters are less severe than first thought, or that matters are not suited for intervention at that moment (see Riksrevisjonen, 2012, p.47). 
The overall activity level would suggest a relatively steady state of 147,000 to 149000 total interventions with families annually between 2014 and 2017 (Statistics Norway, 2018a). It is evident that over these four years there has been a clear shift from residential care to community and family-based interventions, typically fostering. However, across the total interventions the use of evidence-based methods such as PMTO and MST appear to play a minor role. For example, out of the approximately 149,000 interventions in 2017, MST counts for around 800 and PMTO around 1000. Programmes like Functional Family Therapy, Webster Stratton and Marte Meo account for a further 700 interventions (Statistics Norway, 2018a). In this sense, the operation of manualised and evidence-based techniques seems relatively infrequent. Statistics Norway (2018b) provides data on numbers of children involved in children's services and the broad nature of the interventions they receive. It is evident that over the three years 2015 to 2017 actual interventions were relatively steady at $53,439,54,620$ and 55,697 children, of whom approximately $80 \%$ received assistance/preventive support, while care measures for children were likewise stable at $10,069,10,234$ and 10,169 respectively. However, over the same three years there was an 8$9 \%$ increase in notifications of concern (from 54,396 to 58,580) and investigations (from 43,681 to 48,732 ). The same period saw a funded increase in numbers of employees (from 5296 to 6004). The relative weight of activity by employees is clearly upon prevention and family support which comprises the bulk of total measures. As we shall see next, the reverse seems to be the case in Wales.

Children's welfare services in Wales are operated by 22 unitary local authorities and feature a mixed-market of provision. All social workers need to be registered with the independent regulatory body for the profession, Social Care Wales. Most social workers are employed by the local state and conduct statutory duties around child protection investigations, care proceedings, children in need of care and support other than care proceedings (typically, 
disabilities, mental health, children leaving care; families with drug and alcohol misuse). There are also independent sector organisations working with children and families providing residential care, foster care or community-based therapeutic interventions for children and parents with multiple needs. Many of these services are commissioned by local authorities. There is no single piece of legislation that covers child protection or prevention in Wales and it continues to share with England elements of the Children Act 1989 and the Children Act 2004. Recently the Social Services and Wellbeing (Wales) Act 2014 integrates elements of an earlier shared jurisdiction with England and aims over time to shift children's services to a clear preventive and advocacy role (see Social Care Wales, 2017) and provides statutory powers, responsibilities, codes of practice and guidance in regard to safeguarding, investigation of concerns, assessment, planning, interventions and review of cases. The Care Inspection Wales (CIW) regulatory body is funded by Welsh Government and inspects local government and other providers of children's services and reports directly to relevant ministers, particularly about deficient services and can impose improvement plans (see Care Inspectorate Wales, 2018).

Whilst Welsh policy and statute claim an inclusive ethos and preventive ambition for children's services the material facts suggest a much more stressed workforce engaged in the resource-hungry domain of child protection investigations and care proceedings that divert scarce resources from prevention in an unprecedented era of public service austerity (Authors' own 2018). Leading spokespeople for the local authorities in Wales claim a 149\% increase in the number of court applications to place children in care because of harm or its likelihood. Thus in 2008/9 there were 422 applications and in 2017/18 there were 1050; there were 4695 children in care in March 2009 and 6405 in March 2017/18, a rise of over 30\% (see Pollock, 2018). We can note that in 2009/10 local government expenditure in Wales on children’s services was $£ 405 \mathrm{~m}$ and in 2017/18 £613m (Stats Wales, 2018a), this increase has 
been fueled by accelerating numbers of care proceedings and children looked after and thereafter on often expensive specialist residential and fostering care, frequently commissioned from beyond the local authority. During the same period, management and administrative support staff across local authority social services downsized from 2706 to 2517 as did children's domiciliary support staff (from 340 to 226) and support staff in children's community-based day services (from 491 to 341). There were smaller reductions in registered social workers in children's services (1742 to 1717) (Stats Wales, 2018b, 2018c; Social Care Wales, 2018,p.12). Children's social workers are typically involved in assessing the needs of ever more numbers of children coming to notice (40,096 in $2016 / 17$ and 48,069 in 2017/18, Stats Wales, 2018d), of these assessments approximately $20 \%$ convert to a care and support plan (8609 in 2016/17 and 8751 in 2017/18, Stats Wales, 2018d). This suggests that mainly high need / high risk cases succeed in getting an intervention from children's services. Total number of children receiving a service is relatively stable in recent years at around 11,000p.a. Some $40 \%$ of this total are either in care and/or on the child protection register. The remainder are children typically with multiple complex needs and adversities (see Stats Wales, 2018b). In such a context the development of prevention services has limited traction because high risk / high need cases become the pressing focus of limited time and investment.

\section{Surveying the two workforces}

The survey instrument we deployed in both countries was first designed and applied in Norway in 2014 (see Authors' own 2018) and contained some 40 multiple choice questions addressing a range of demographic characteristics and work-related activities and experiences including use of time, knowledge and competence, decision-making and discretion, evidencebased practice, aims of social work and matters of quality. Our focus is on a subset of 
questions around management, time on front line work, satisfaction over practice, decisions and discretion as these relate more strongly to our focus on autonomy and NPM.

\section{Norway}

The survey was not reported to the Norwegian Centre for Research Data for ethical approval, as the instrument would not identify any individual or place of work. Norway has no national regulatory body to which all workers must register thus a sample was identified from the membership lists of the Norwegian Union of Social Educators and Social Workers which enjoys registration of around $70-80 \%$ of Norway's social workers. The instrument was sent by email (Questback) and targeted at all practitioners $(n=4916)$ in four counties in western Norway. These localities consist of rural and urban communities. The response rate was 2060 (over $40 \%$ ) and of these some 482 worked with children and their families. Most of these $(67 \%)$ worked in the municipal Child Welfare Services as front line personnel and the remainder at state level. While there is no reason to think that their responses would be different from a national sample, we cannot claim external validity for the respondents as representative of all Norway's practitioners. Most (83\%) were women which is consistent with the national gender distribution amongst social workers (Dahle, 2010). The typical social work qualification is at bachelor's degree and a minority of $7.5 \%$ have a master`s degree, very few have a $\mathrm{PhD}$ (see also Norwegian Ministry of Education and Research, 2012). Their average age is mid-forties; some $33 \%$ are 50 years or older and $11 \%$ are 30 years or younger. Some $48 \%$ had been with their present employer for less than five years; $52 \%$ for five years or more; $23 \%$ for 11 years or more. Notably, some $80 \%$ had more than five years' experience of front-line practice. In brief, the workforce would seem to be mainly female, aging, qualified at graduate level, and a strong majority with several years of direct 
experience, suggesting a durable and long serving professional body. There are clear similarities here with the Wales' workforce data.

\section{Wales}

A closely translated version of the Norwegian survey instrument was piloted with registered social workers and academic colleagues in Wales; small adjustments were made to the terminology to clarify and sequence the questions smoothly. An online survey was used as participants tend to respond more quickly than other survey modes and the need for researchers to input data before analysis can begin is removed (Callegaro et al., 2015). Anonymous web links to the survey were distributed by the national registration body, Social Care Wales (SCW), who helped promote the study to the workforce. Ethical approval was provided by a joint academic/SCW panel, who were satisfied that neither the questions nor the anonymised web links would generate data that could identify any individual and this commitment was communicated to participants in the SCW invitation to registrants. Some 5,965 social workers registered by Social Care Wales as employed, were distributed anonymous links to the survey via email and 997 responded. This translates to a response rate of approximately $17 \%$. While this is lower than the response rate in Norway, the sample is still representative of social workers in Wales. Comparisons between the final survey sample and Social Care Wales membership data revealed no statistically significant differences in regard to key demographic variables including gender. Of the respondents, 348 reported that their main field of practice was child and family and we focus on these respondents only. While our overall sample could claim strong external validity, we could not be certain this was the case for the much smaller sub-sample of children's workers and, as in Norway, we present our data as non-representative and cross-sectional in time and place. 
As in Norway, most of our sample were female (81\%) with an average age of 43 to 52 and some $11 \%$ are 32 or younger. As in Norway, $68 \%$ of the workforce were mainly located in local government (Norway 67\%), and most were educated and qualified at undergraduate with many older workers qualified at (former) diploma level. More workers in Wales (11\%) than in the Norwegian sample $(7.5 \%)$ had a Master's degree. Most $(76 \%)$ had over five years frontline experience, similar to the $80 \%$ in the four Norwegian counties. Some $60 \%$ had been with their present employer for much more than 5 years compared to $52 \%$ in Norway. In brief, both samples comprise a largely female and aging workforce which appears to be durable and front-line experienced (with exceptions in some local authorities, see Care Inspectorate Wales, 2018).

\section{Results}

We now turn to the comparison in respect of key areas of practice, discretion, and work-place relationships.

[Table 1 near here]

Practitioners' own management and administration of their caseloads seems to be of clear importance in both Norway and Wales but more so in the latter where there are statistically significant differences. In Wales, it may be that their occupational gestalt as predominantly local authority bureau-professionals focused largely on fields of risk disposes them to screenbased administrative tasks as essential and part of defensive practice in an occupational group often blamed by the media for scandals and tragedies surrounding children (Munro, 2011a, 2018b). Yet, Norwegian workers endorse such activities too; thus, despite very different welfare systems it is likely that both samples operate mainly in statutory settings where case administrative tasks are now viewed by current generations (unlike their forbears in Wales - 
Authors' own 1987) as a normative part of core professional activity, important and in any event unavoidable.

[Table 2 near here]

In Table 2 we see a distinctive statistical difference. In Norway, more time is spent by respondents on frontline social work. In Wales $78 \%$ state they use less than $40 \%$ of their working week on frontline work with clients, while $50 \%$ spend less than $40 \%$ of their working week on this kind of task in Norway. Also notable is the clear difference between those who use above $60 \%$ of their working week on frontline work $-6 \%$ in Wales and $30 \%$ in Norway. This tendency in Wales to be located more on screen-work and other bureau-based activities suggest that workers become more immersed and habituated to the meanings, relationships and the rewards of that environment. Their limited interaction with clients, often in regard to assessment, planning and review, clearly has implications for time available to engage in therapeutic time-consuming practice (Authors' own 2018). As in other UK research (Hardy, 2016; Holmes and McDermid 2013) the administrative time-demands of practice seem to eclipse that which is available for service users. By contrast, some $50 \%$ of Norwegian respondents claim to spend under $40 \%$ of the working week in face to face contact. Their evident mobility outside the bureau in family homes or other settings with clients would suggest much less direct involvement with office routines. In this regard they appear to display more affinity with classical street-level types of workers enjoying closer connections to citizens in local communities and operating with evident discretion over types of intervention (Lipsky, 2010).

[Table 3 near here] 
We can see some similarity between Wales and Norway on whether it is possible to perform tasks satisfactorily, albeit the latter scores higher for those in agreement to a large or very large degree at $55 \%$ compared to Wales $43 \%$. Were we to imagine that Wales' workers might view their involvement in administrative tasks that keep them from client-facing practice as an impediment to performance, then we might have predicted bigger differences between the two countries. However, it is evident that both sets of respondents tend to view their current positions as conducive to completing their task satisfactorily. Table three invites the participants to judge their 'real world' circumstances as the basis for measurement rather than some ideal set of conditions and thereby perceive their performance in line with what is realistically achievable within their own domain. (Such 'normativity' might also be accompanied by a research effect in which participants seek to project a positive image of themselves to others, see Jones, 1996, p. 204) In any event, it is evident that social workers operating in these very different welfare regimes still view their work as satisfactory and thus do not seem to evaluate their activities in line with some external (and global) benchmark for social work albeit such of course exists (International Federation of Social Work, 2018).

[Table 4 near here]

By professional judgement we mean the expertise brought to bear to propose a particular option or action. Again, there is a statistically significant difference between Wales and Norway. In brief, there would seem to be stronger possibilities in Norway for exercising professional judgement but not markedly so. Again, we might observe that professional judgement occurs within pre-defined jurisdictional and occupational cultures, and despite the more preventative and 'street-level' nature of practice in Norway and the more administrative and risk-oriented character of intervention in Wales, both sets of respondents seem to enjoy the possibility of exercising judgement but within their respective contexts and as we shall see, these contexts influence decision-making and discretion. 
[Table 5 near here]

Here we find a further statistically significant difference between Norway and Wales. The values 'to a large' or 'very large degree' show the picture more clearly about freedom to make decisions: Wales $52 \%$ and Norway $74 \%$. It would seem that workers in Wales are much more indexed to their local government bureaux in which administrative activity and case decisions collect around high-risk concerns and related compliance with recording procedures. By contrast, decisions appear more decentralised to front-line practitioners in Norway's more preventive and well-resourced service that allows workers discretion to work around organisational or policy impediments they consider may not be in the child or family's best interests (see Kritz \& Skivenes, 2014).

[Table 6 near here]

Whilst both sets of respondents consider their work to be satisfactory and that they are able to make judgements and (to varying degrees) take decisions, this is in the context of their own work milieu and available materials. More stark differences now surface about the matter of resource and worker capacities to customise their intervention in line with client needs. Thus, in Wales $56 \%$ partly or totally agreed with the proposition that there are few possibilities to offer individually tailored services compared to $32 \%$ in Norway. Bespoke interventions would seem to be much more likely in Norway and points once more to the availability of preventive options and capacity for workers to decide on how to select and deliver these. In Wales, the 'real world' of straitened public services dealing increasingly with high risk cases seems unlikely to permit, for the foreseeable future, a more bespoke and better resourced approach to professional discretion. 
[Table 7 near here]

Here, we draw upon respondents with a minimum of $10+$ years practice experience in order to capture any changes over time to worker opportunities to exercise discretion in the workplace. We see a marked and statistically significant difference. A small majority of Norwegian respondents, $54 \%$, think the opportunity for discretion remains the same as it has always been, implying some stability over the way they practice but $32 \%$ consider discretion to have reduced. In Wales $47 \%$ think the opportunity for the use of discretion has reduced and $36 \%$ think it has remained the same. Interestingly, $17 \%$ in Wales think the opportunity for discretion has become greater. It is not possible to access the fine grain of these responses regarding what precisely has changed in the exercise of discretion and over what time period. We may speculate that the modest increase seen by some in Wales represents the early signs of change brought by the new Social Services and Well-Being (Wales) Act (2014) which aims to shift practice to a more preventive and creative co-production between worker and client. [Table 8 near here]

There is a statistically significant difference with regard to this question. Norwegians are more likely to look forward going to work compared to their counterparts in Wales. The value 'to a large' and 'very large degree' shows this: $64 \%$ in Norway compared to $40 \%$ in Wales. Were we to include 'to some degree', then $93 \%$ in Norway and $74 \%$ in Wales. Crosstabulation of the data in Table 8 with the findings in Tables 1-7 show very clearly that the experience of having freedom to perform professional discretion and to perform one`s tasks satisfactorily, correlates strongly with the tendency of looking forward to going to work.

\section{Discussion}

The above comparisons suggest that professionals from both countries share broadly in the importance they place upon their personal management and administration of their own 
caseloads and do not seem to view this as an undesirable diversion from practice. Indeed, both sets of workers are of the view that they perform their core professional tasks satisfactorily. Yet data indicate statistically significant differences in regard to decision making and use of discretion. Workers in Wales were much more likely to claim limited capacity in these two critical aspects of practice compared to Norwegian respondents and likewise there were statistical differences over capacity to provide bespoke services, with Norway again likely to outstrip Wales in this domain. Furthermore, crosstabulations found clear correlations between exercising discretion and performing one`s tasks satisfactorily with a tendency to look forward going to work. It was unsurprising therefore to note that Norwegian workers looked forward to going to work more so than those in Wales, but the latter were not that far behind. In order to trace the likely roots of these significant differences we return briefly to systemic features of occupational context.

In Wales and England, practice can be seen as rooted in a complex mix of a decade's resource austerity (Welsh Government 2018) coupled to an earlier period of regulatory reforms culminating in new screen-based technologies that would establish fairly impermeable work-flow processes in local authority children's social work services (see Wastell et al., 2010). This left many practitioners in the narrowly focused role of case manager, assessing needs, analysing risk, planning and reviewing interventions, outsourcing therapeutic work whilst often acting as gatekeepers of scarce resources. In short, high-risk caseloads mean that contemporary practice is rarely about prevention but more about targeting and keeping children 'safe' as there is insufficient time and provision for workers to engage more therapeutically in complex cases (Care and Social Services Inspectorate Wales, 2014; 2016). 
By contrast, social workers in Norway are exposed to comparatively few impermeable rules governing the decision process. Whilst municipal services are required to follow timelines, such as into notifications of concern, in doing so there are multiple opportunities to use discretion when it comes to intervening or not, and in following up on initial responses. In Norway, a combination of well-funded universal provision and a flexible and inclusive approach to remedies permits, intentionally or otherwise, a wide sphere of operations that facilitate practitioner autonomy. This does not suggest a lack of administrative accountability, rather there is emphasis upon epistemic accountability, that is, support for the quality of professional judgements and ways to strengthen these, rather than imposing strict mechanisms of formal control. A sense of political and public consensus over the virtues and value of social work and its adequate resourcing would seem to lie at the root of this phenomenon (see Molander, 2013).

\section{Conclusion}

We have sought to explore the assumption that a defining characteristic of NPM is typically one of diminishing the spheres of professional autonomy in human service organisations through various forms of benchmarking, surveillance, evidence based practices, accountability, documentation and work-flow routines that shift power from professionals to the bureau administrative environment. In examining this claim, we set out two broad orientations regarding the impact of NPM on professional autonomy that informed our study 
design and interpretation of findings. The first was Orientation 1 in which the social worker is a bureau-professional with circumscribed autonomy, overly engaged in risk-targeted practice that is subject to screen-work, scarce provision and safety oriented towards children. Workers in Wales compared to those in Norway are more aligned to this position, insofar as they spent less time with service users and more time on office-based routines, had much less capacity to advance bespoke solutions, enjoyed less discretion and control over decisions than those in Norway. Yet they considered their practice as satisfactory and most looked forward to going to work. In this sense, we may speculate that (a) professional autonomy exists in Wales to the extent that it makes practice meaningful and intrinsically rewarding and/or (b) professional autonomy is not the sole or necessarily major determinant of how workers view their activities as meaningful and intrinsically rewarding. Thus, while features of NPM appear prominent in the Welsh context this has not, in this study, revealed itself in worker dissatisfaction with their practice. Doubtless other aspects of the occupational experience will lead practitioners operating in conditions where NPM is present, to consider their efforts as worthy and themselves as virtuous (Authors' own 2019) and we do not speculate on what these may be here. We conclude only that the everyday 'habitus' of daily bureau work, will necessarily shape perceptions of what is satisfactory practice and a rewarding experience and that workers are less likely to measure their endeavours against some alternative 'benchmark' offered by the academy or professional representative bodies (Authors' own 2018).

By contrast, the Norway sample operate much closer to our Orientation 2, whereby NPM is less restrictive insofar as compliance and control within a complex bureaucratic structure is subject to moderation by street-level worker autonomy and rule interpretation. While rules and frames of practice seek to shape interventions, such as the use of manualised evidencebased methods, it is clear that practitioners applied much control over their approach to supporting families and children. Overall, the data indicate that while both samples viewed 
case-based administrative routines as important features of the job, and while both samples were satisfied with their practice, it was evident that Norwegian workers enjoyed much more freedom and space over their approach to interventions. They applied significantly more front-line discretion in order to deliver bespoke preventative family focused support. Were we to support the view that a less trammelled administrative structure and creative worker autonomy is considered best to advance flexible, and creative solutions in social work (see Samsonsen \& Turney, 2017), then it would be hard to resist the conclusion that the Norwegian model offers much to commend. However, such a model is not in the gift of social work and much depends upon the relationship between state and citizen. Borrowing Esping Andersen's (1989) classic typology, the universal inclusive and relatively high-tax welfare state underpins a preventative flexible social work practice in Norway. In devolved Wales, linked for a decade to the austerity measures of a low-tax neo-liberal UK government, there are nonetheless clear ambitions in domestic policy and legislation that would move social work away from narrow NPM orientations to a more preventive and creative set of relationships and interventions. But as ever, aspiration coupled to insufficient resources makes for difficult travelling companions and without marked reflation by UK government of public service budgets in Wales, change is likely to be slow in coming. 


\section{References}

Authors' own 1987, 2015, 2018.

Callegaro, M., Manfreda, K. \& Vehover, V. (2015). Web Survey Methodology, London: Sage. Care Inspectorate Wales. (2018). Significant improvement achieved in Powys but serious concerns remain - report. (https://careinspectorate.wales/inspection-childrens-services-powys-countycouncil-jan-2019) (accessed January 2019).

Care and Social Services Inspectorate. (2014). National Inspection of safeguarding and care planning of Looked after Children and Care Leavers who exhibit vulnerable or risky behaviours, Cardiff, CSSIW.

Dahle, R. (2010). Sosialt arbeid-en historie om kjønn, klasse og profesjon [Social work-A history about gender, class and profession]. Tidsskrift for Kjфnnsforskning, 34, 41-56.

Dubois, V. (2010). The Bureaucrat and the Poor: Encounters in French Welfare Offices. Farnham: Ashgate.

Esping-Andersen, G. (1989). The Three Political Economies of the Welfare State. The Canadian Review of Sociology and Anthropology, 26(1), 10.

Evans, T. \& Harris, J. (2004). Street-Level Bureaucracy, Social Work and the (Exaggerated) Death of Discretion. British Journal of Social Work, 34(6), 871-895.

Freidson, E. (2001). Professionalism, the third logic: on the practice of knowledge. Chicago: University of Chicago Press.

Frostenson, M. (2015). Three forms of professional autonomy: De-professionalisation of teachers in a new light. Nordic Journal of Studies in Educational Policy, 1(2), 20-29. 
Gautun, H. (2009). Det nye barnevernbyråkratiet. En studie av samarbeid mellom kommune og stat innen barnevernet. [The new bureaucracy of the Children`s services. A study of cooperation between municipalities and the state] (Fafo-rapport 41). Oslo: Fafo.

Grimen, H. \& Molander, A. (2008). Profesjon og skjønn [Profession and discretion]. In A. Molander \& L. Terum, (Eds), Profesjonsstudier [Studies of professions] (pp. 179-196). Oslo: Universitetsforlaget.

Holmes, L. \& McDermid, S. (2013). How social workers spend their time in frontline children's social care in England. Journal of Children's Services, 8(2), 123-33.

Hood, C., \& Dixon, R. (2015). A government that worked better and cost less?: Evaluating three decades of reform and change in UK central Government. OUP: Oxford.

Hupe, P. (2013). Dimensions of Discretion: Specifying the Object of Street-Level Bureaucracy Research. der moderne staat-Zeitschrift für Public Policy, Recht und Management, 6 (2), 425-440.

International Federation of Social Work. (2018). Global Social Work Statement of Social Work Principles. (https://www.ifsw.org/wp-content/uploads/2018/07/Global-Social-WorkStatement-of-Ethical-Principles-IASSW-27-April-2018-1.pdf). (accessed January 2019).

Jones, R. (1996). Research Methods in the Social and Behavioural Sciences. Mass,: Sinauer Associates.

Kritz ,K. \& Skivenes, M. (2014). Street-level policy aims of child welfare workers in England, Norway and the United States: An exploratory study. Children and Youth Services Review, 40(1), 71-78. 
Krogh, J. (2009). Den raske overføringen av Multisystemic Therapy (MST) fra USA til Norge. En analyse og en problematisering [The rapid transfer of MST from the USA to Norway. An analysis and a query]. Norges Barnevern, 2, 100-112.

Lipsky, M. (2010). Street-level bureaucracy: dilemmas of the individual in public services. (30th anniversary expanded edition). New York: Russell Sage Foundation.

March, J., \& Olsen, P. (1989). Rediscovering Institutions: The Organizational Basis of Politics. New York: Free Press.

Molander, A. (2013). Profesjonelt skjønn i velferdsstaten: mekanismer for ansvarliggjøring [Professional judgement in the welfare state: Mechanisms for accountability]. In A. Molander \& J. C. Smeby (Eds.), Profesjonsstudier II [Studies of professions II] (pp. 44-54). Oslo: Universitetsforlaget.

Munro, E. (2011a). The Munro Review of Child Protection: Final Report a Child-Centred System. London: Department for Education.

Munro, E. (2018b). Decision-making under uncertainty in child protection: Creating a just and learning culture. Child \& Family Social Work, Advance Access published 4 July 2018, doi: $10.1111 /$ cfs. 12589 .

Newman, J. (2014). Professionals, power and the reform of public services. In M. Noordegraaf \& Steijn, B. (eds). Professionals under pressure: The reconfiguration of professional work in changing public services (pp.41-53). Amsterdam: Amsterdam University Press.

Nordstoga, S., \& Støkken, A. (2009). Barnevernsinstitusjoner og markedsbyråkrati [Child welfare institutions and market bureaucracy]. Oslo: Universitetsforlaget. 
Norwegian Ministry of Education and Research. (2012). Utdanning for velferd. Samspill $i$ praksis [Education for welfare. Cooperation in practice] (White Paper No. 13 [2011-2012]). Oslo, Norway: Author.

Pollock, I. (2018). Children's Services in Wales in 'near crisis', BBC News, UK/Wales, accessed January 2019. (https://www.bbc.co.uk/news/uk-wales-43951732).

Riksrevisjonen. (2012). Riksrevisjonens undersфkelse om det kommunale barnevernet og bruken av statlige virkemidler [The Office of the Auditor General of Norway`s analysis of municipal Child Welfare Services and the use of governmental means]. Dokument 3:15 (2011-2012).

Samsonsen, V., \& Turney, D. (2017). The role of professional judgement in social work assessment: A comparison between Norway and England. European Journal of Social Work, 20(1), 112-124.10.1080/13691457.2016.1185701.

Social Care Wales (2017). Overview: Social Services and Well-being (Wales) Act, 2014, SCW Learning Hub, (https://socialcare.wales/hub/sswbact), (accessed January 2019).

Social Care Wales (2018). Social Worker Workforce Planning 2016/17. (https://socialcare.wales/research-and-data/workforce-reports). (accessed January 2019). Statistics Norway (2018a). 10660: Measures from the Child Welfare Services, by type of measures, contents and year.

(https://www.ssb.no/en/statbank/table/10660/tableViewLayout1/?loadedQueryId=10003479 \&timeType=top\& timeValue=4). 
Statistics Norway (2018b). Main figures for the Child Welfare Services statistics.

(https://www.ssb.no/en/sosiale-forhold-og-kriminalitet/statistikker/barneverng).

Stats Wales (2018a). Social Services Revenue Outturn expenditure by client group ( $£$ thousand). (https://statswales.gov.wales/Catalogue/Local-

Government/Finance/Revenue/Social-Services/social-services-

socialservicesrevenueexpenditure-by-clientgroup). (accessed January 2019).

Stats Wales (2018b). Children in Need by Local Authority and Looked After Status.

(https://statswales.gov.wales/Catalogue/Health-and-Social-Care/Social-Services/Childrens-

$\underline{\text { Services/Children-in-Need/childreninneed-by-localauthority-lookedafterstatus) (accessed }}$ January 2019).

Stats Wales (2018c). Local authority social services - Staff numbers in Wales, 31 March

2018. ( https://statswales.gov.wales/Catalogue/Health-and-Social-Care/Social-

Services/Staffing/staffoflocalauthoritysocialservicesdepartments-by-localauthority-posttitle). (accessed January 2019).

Stats Wales (2018d). Assessments by Local Authority and Measure.

(https://statswales.gov.wales/Catalogue/Health-and-Social-Care/Social-Services/ChildrensServices/Service-Provision/assessments-by-localauthority-measure). (accessed January 2019).

Wastell, D., White, S., Broadhurst, K., Hall, C., Peckover, S., \& Pithouse, A. (2010).

Children's services in the iron cage of performance management: street level bureaucracy and the spectre of Švejkism. International Journal of Social Welfare, 19, 310-320.

(doi: $10.1111 / \mathrm{j} .1468-2397.2009 .00716 . x$ ). 
Welsh Government (2018). A Healthier Wales: Our Plan for Health and Social Care.

(https://gov.wales/topics/health/publications/healthier-wales/?lang=en). (accessed July 2018). 


\section{Tables}

Table 1. How important are the following tasks in your work: Case Management and Administration? (values are percentages of respondents; $N=839$ ).

Wales Norway

Not Important/Less Important

9.5

Important

$24.3 \quad 19.5$

Quite Important/Very Important

$66.2 \quad 57.2$

Pearson's Chi-Square $p<.001$.

Table 2. Percentage of your typical working week spent on following tasks: Frontline Social

Work (face to face) (values are percentages of respondents; $N=847$ ).

Wales Norway

Under $40 \%$

$\begin{array}{ll}77.9 & 50.3\end{array}$

$40-60 \%$

$16.6 \quad 19.3$

Above $60 \%$

$5.5 \quad 30.4$

Pearson's Chi-Square $p<.001$. 
Table 3. To what degree does your current position make it possible to perform your tasks satisfactorily? (values are percentages of respondents; $N=852$ ).

\section{Wales Norway}

To a very small or small degree

17.6

To some degree

To a large or very large degree

Pearson's Chi-Square $p<.001$.

Table 4. To what degree does your position make it possible to exercise professional judgement to an adequate level? (values are percentages of respondents; $N=851$ ).

\begin{tabular}{lcr}
\hline & Wales & Norway \\
\hline To a very small or small degree & 8.9 & 2.8 \\
To some degree & 29.1 & 29.2 \\
To a large or very large degree & 62.0 & 68.1
\end{tabular}

Pearson's Chi-Square not statistical significant at $p<.001$. 
Table 5. To what degree does your current position allow you freedom to make decisions? (values are percentages of respondents; $N=846$ ).

Wales Norway

To a very small or small degree

$13.3 \quad 2.4$

To some degree

$34.6 \quad 23.0$

To a large or very large degree

52.2

74.5

Pearson's Chi-Square not statistical significant at $p<.001$.

Table 6. Consider the following: In my work, there are few possibilities to offer individually tailored services (values are percentages of respondents; $N=853$ ).

Wales Norway

Totally/Partly disagree

37.2

62.6

Unsure

6.9

Partly/Totally agree

55.9

Pearson's Chi-Square $p<.001$. 
Table 7. Thinking about discretion in the workplace please consider which of the following matches your current experience (values are percentages of respondents; $N=527$ - only respondents qualified before 2006).

Wales Norway

The opportunity for the use of discretion has become greater

$16.9 \quad 13.7$

The opportunity for the use of discretion is about the same as it always

has been

The opportunity for the use of discretion has reduced

47.3

Pearson's Chi-Square $p<.001$.

Table 8. To what degree do you look forward going to work? (values are percentages of respondents; $N=852$ ).

\section{Wales Norway}

To a very small/small degree

To some degree

To a large /very large degree

40.2

Pearson's Chi-Square $p<.001$. 